\title{
IMPLEMENTASI JALINAN SISTEM ANTARA GENERAL RULES DENGAN SPECIAL RULES DALAM SISTEM PEMIDANAAN SUBSTANTIF
}

\author{
Eko Soponyono \\ Fakultas Hukum Universitas diponegoro \\ Email : eko.soponyono@gmail.com
}

\begin{abstract}
Implementation of the system fabric between "general rules" with "special rules" in the substantive criminal system can not be separated from the criminal system policy will be pursued by members of the House of representatives in understanding all juridical problems are there to make a better one. Implementation of the system fabric between "general rules" with "special rules" in the substantive criminal system in Indonesia is not always ideal, because the neglect of understanding of the system of punishment in the criminal code. These conditions can be further complicated when the New penal code bill with no reforming indication intelligently addressed by the Legislature in policy formulation. Based on the above reasons, this report is organized in the hope of giving firmness to the interested student attitudes material criminal law, Law Enforcement Authorities, especially Holders Policy Formulation Phase (the Legislature).
\end{abstract}

Keywords: Integrated Systems, general rules, Special rules, Sentencing System

\begin{abstract}
Abstrak
Implementasi jalinan sistem antara "general rules" dengan "special rules" dalam sistem pemidanaan substantif tidak dapat dipisahkan dengan kebijakan sistem pemidanaan yang akan ditempuh oleh anggota DPR dalam memahami semua permasalahan juridis yang ada untuk membuat yang lebih baik. Implementasi jalinan sistem antara "general rules" dengan "special rules" dalam sistem pemidanaan substantif di Indonesia tidak senantiasa ideal, karena terabaikannya pemahaman atas sistem pemidanaan dalam ketentuan induknya di KUHP/WvS. Kondisi demikian bisa akan lebih rumit lagi ketika RUU KUHP Baru dengan indikasi kebaharuannya tidak disikapi secara cerdas oleh Badan Legislatif dalam kebijakan formulasinya. Berdasar alasan di atas, tulisan ini disusun dengan harapan dapat memberi ketegasan sikap bagi mahasiswa peminat hukum pidana materiil, Aparat Penegak Hukum, terutama Pemegang Kebijakan Tahap Formulasi (Badan Legislatif ).
\end{abstract}

Kata Kunci: Jalinan Sistem, Ketentuan Umum, Ketentuan Khusus, Sistem Pemidanaan

\section{A. Pendahuluan}

Wetboek van Strafrecht voor NederlandshIndie milik Belanda disusun berdasarkan filosofi individualisme-liberalisme, oleh Undang-Undang Nomor 1 Tahun 1946 Pasal 6: (1) Nama Undang-undang hukum pidana "Wetboek van Strafrecht voor Nederlandsh-Indie" dirobah menjadi "Wetboek van Strafrecht". (2) Undangundang tersebut dapat disebut: "Kitab UndangUndang Hukum Pidana"/KUHP.

Fenomena kebijakan formulasi ketentuan perundang-undangan di luar KUHP/WvS oleh Badan Legislatif setelah Proklamasi Kemerdekaan 17 Agustus Tahun 1945 yang selalu ada dari tahun ke tahun, merupakan bukti bahwa kebutuhan akan hukum yang filosofinya dari masyarakat Indonesia tidak mungkin dapat dipungkiri. Kebutuhan akan ketentuan perundang-undangan (pidana) meskipun landasan filosofinya berasal dari masyarakat tempat ketentuan perundangundangan di susun tidak berarti bahwa kebijakan formulasinya mengabaikan sistem pemidanaan dari kodifikasi sebagai sistem induknya ( KUHP/ WvS). Ketentuan pidana baik dalam KUHP/ WvS maupun dalam ketentuan perundang-undangan di luarnya diformulasikan dalam jalinan sistem dan kemudian diketahui sebagai "Sistem Pemidanaan".

Secara teoritik "Sistem Pemidanaan" yang bermakna suatu proses bagaimana seseorang yang telah melakukan tindak pidana dijatuhi pidana, dapat dipahami sebagai makna yang luas dan sempit. Makna luas/fungsional sistem pemidanaan meliputi; sub-sistem hukum pidana materiil, sub-sistem hukum pidana formil dan sub-sistem hukum pelaksanaan pidana. Makna sempit/substantif sistem pemidanaan meliputi; sub-sistem general rules/Aturan Umum dan Special rules/Aturan Khusus. 
Sistem pemidanaan dari sudut substantif/ sempit merupakan keseluruhan aturan perundangundangan yang berkaitan dengan pidana dan pemidanaan. L.H.C Hulsman mengemukakan makna sistem pemidanaan dengan "The sentencing system is the statutory rules relating to penal sanction and punishment (Barda Nawawi Arief, 2007, 1). Dalam makna demikian sistem pemidanaan terkait dengan ketentuan pidana, sehingga Barda Nawawi Arief lebih menegaskan, bahwa sistem pemidanaan merupakan suatu proses pemberian atau penjatuhan pidana oleh hakim, sehingga dia mencakup keseluruhan ketentuan perundang-undangan yang mengatur bagaimana hukum pidana ditegakkan atau dioperasionalisasikan secara konkret sehingga seseorang dijatuhi sanksi (hukum) pidana ( Barda Nawawi Arief, 2007 : 1).

Pengertian sistem pemidanaan yang dikemukakan oleh L.H.C Hulsman di atas meliputi "Aturan Umum"/"general rules" dan "Aturan Khusus"/"Special rules". Keterjalinan antara kedua aturan tersebut ada dalam rumusan Pasal
103 KUHP/WvS berbunyi; "Ketentuan-ketentuan dalam Bab I sampai dengan Bab VIII buku ini juga berlaku bagi perbuatan-perbuatan yang oleh ketentuan perundang-undangan lainnya diancam dengan pidana, kecuali jika oleh undang-undang ditentukan lain". Bab I sampai dengan Bab VIII berada dalam Buku Kesatu KUHP/WvS dan terdiri dari rumusan Pasal 1 sampai dengan Pasal 85, sedang Bab IX terdiri dari Pasal 86 sampai dengan Pasal 101 (Moeljatno, 1999 : 40). Ketentuan Pasal 1 sampai dengan Pasal 85 KUHP/WvS merupakan sub -sistem dari sistem pemidanaan dan merupakan suatu keterjalinan yang utuh, artinya keterjalinan yang tidak dapat dipisahlepaskan antara "Straf Soort, Straf Maat dan Straf Modus dengan sub-sistem Pedoman dan Aturan Pemidanaan".

Keterjalinan yang utuh sebagai suatu ikatan yang tidak dapat dipisah-lepaskan antara "strafsoort, strafmaat dan strafmodus dengan subsistem Pedoman dan Aturan Pemidanaan" dapat dipahami dari bagan berikut ini.

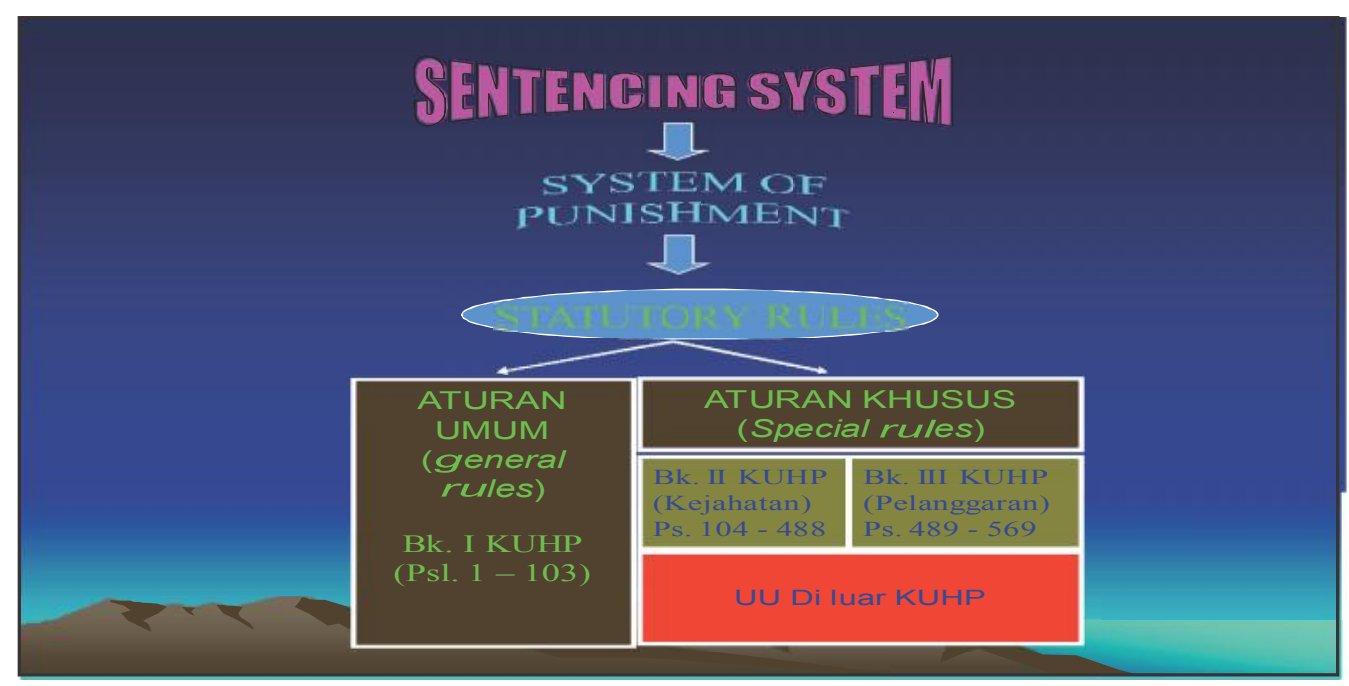

Bagan Tentang Sistem Pemidanaan Dalam Arti Sempit ( Sumber : Barda Nawawi Arief, Perkembangan Sistem Pemidanaan di Indonesia, Pustaka Magister, Semarang 2007, hal. 5)

Mendasarkan pada uraian di atas, maka tulisan ini mengkaji apakah ketentuan pidana dalam ketentuan perundang-undangan di luar KUHP/WvS terkait secara sistem dalam jalinan sistem antara "general rules" dengan "special rules" dalam sistem pemidanaan substantif Berpijak pada pendahuluan di atas, maka permasalahan yang disusun, adalah implementasi jalinan sistem antara general rules dengan special rules dalam sistem pemidanaan substantif saat ini dan implementasi jalinan sistem antara general rules dengan special rules dalam sistem pemidanaan substantif yang akan datang?

\section{B. Metode Penelitian}

1. Pendekatan Masalah

Permasalahan dalam penelitian ini termasuk masalah sentral dari kebijakan penal, merupakan bagian dari kebijakan 
kriminal. Oleh karena itu pendekatannya tidak dapat dipisahkan dari pendekatan yang berorientasi pada kebijakan (policy oriented approach). Hakikat penelitian ini adalah menganalisa kebijakan legislatif/formulatif dalam menetapkan dan merumuskan sistem hukum pidana/sistem pemidanaan dalam pengertian substansial dalam jalinan system antara general rules dengan Special rules. Oleh karena itu pendekatan dalam penelitian ini adalah penelitian hukum normatif. Dalam penelitian hukum normatif digunakan beberapa pendekatan, yaitu pendekatan perundang-undangan (statute appproach) dan pendekatan konseptual (conceptual approach).

\section{Spesifikasi Penelitian}

Spesifikasi Penelitian yang dilakukan dalam menyusun makalah ini seperti adalah penelitian hukum normatif atau penelitian hukum kepustakaan. Penelitian hukum normatif atau kepustakaan dengan menelaah taraf sinkronisasi dengan mengkaji jalinan system antara Aturan Umum dengan Aturan Khusus dalam ketentuan perundangundangan. Dalam penelitian terhadap taraf sinkronisasi horisontal bermaksud meneliti sejauh mana tingkat keserasian/keterjalinan sistem antara system induk dalam KIUHP/ WvS dengan Ketentuan Pidana Buku II dan Buku III dan Ketentuan Pidana dalam ketentuan perundang-undangan di luar KUHP/WvS.

\section{Jenis dan Sumber data}

Jenis dan data dalam penelitian ini adalah data sekunder. Data yang bahan-bahannya diambil dari pustaka/bahan-bahan pustaka. Data sekunder yang diteliti terdiri dari;

a. Bahan hukum primer, yaitu bahan-bahan hukum yang mengikat terdiri dari:

1) Peraturan Perundang-undangan yang di dalamnya mencantumkan ketentuan pidana dan pemidanaan.

2) Bahan hukum dari zaman penjajahan yang hingga kini masih berlaku seperti, Kitab UndangUndang Hukum Pidana /KUHP/WvS (Wetboek van Strafrecht).

b. Bahan hukum sekunder, yang memberikan penjelasan mengenai bahan hukum primer, seperti rancangan undang-undang (yang diteliti meliputi; Konsep RUU KUHP Baru Tahun 2012).

\section{Metode Pengumpulan data}

Berpijak dari penelitian yang dilakukan dengan memusatkan perhatian pada data sekunder, maka bahan hukum primer maupun bahan hukum sekunder dikumpulkan berdasarkan perumusan masalah yang telah ditetapkan, kemudian diklasifikasi menurut sumber dan hierarkinya untuk dikaji secara komprehensif.

\section{Metode Analisis data}

Seluruh data dan informasi yang diperoleh dalam penelitian ini dianalisis dengan menggunakan metode analisa kualitatif normatif. Penggunaan metode analisis kualitatif normatif ini sangat berkaitan dengan permasalahan yang dibahas, seperti yang telah dikemukakan dalam perumusan masalah. Analisis kualitatif normatif terhadap data yang disajikan secara kuantitatif, berpijak pada analisis deskriptif dan prediktif.

Permasalahan pertama yaitu "Bagaimana implementasi jalinan sistem antara general rules dengan special rules dalam sistem pemidanaan substantif saat ini" dijawab dengan analisis deskriptif. Berbagai langkah nyata yang dilakukan untuk menjawab permasalahan pertama ini dengan melakukan inventarisasi ketentuan perundang-undangan. Analisis deskriptif terhadap ketentuan perundang-undangan meliputi ketentuan pidana, tindakan dan pemidanaan. Data yang diperoleh kemudian dianalisa dengan menggunakan metode analisis kualitatif normatif terhadap implementasi jalinan sistem antara general rules dengan special rules dalam sistem pemidanaan substantif saat ini dalam ruang lingkup hukum pidana materiil. Hasil analisis tersebut memberikan deskripsi/ gambaran tentang implementasi jalinan sistem antara general rules dengan special rules dalam sistem pemidanaan substantif saat ini.

Permasalahan kedua yaitu "Bagaimana implementasi jalinan sistem antara general rules dengan special rules dalam sistem pemidanaan substantif yang akan datang ?. Permasalahan tersebut diprediksikan dan dipadukan dengan Konsep RUU KUHP Baru. Hasil analisis terhadap permasalahan kedua dengan indikasi kebaharuannya terkait dengan respon Badan Legislatif dalam kebijakan formulasinya.

\section{Hasil Penelitian dan Pembahasan}

1. Konsep Sistem Pemidanaan Substantif 
Sistem pemidanaan (sentencing system) merupakan keseluruhan aturan perundangundangan yang berkaitan dengan pidana dan pemidanaan. Dalam makna demikian, sistem pemidanaan terkait dengan sanksi pidana dan pemidanaan, karenanya dia merupakan suatu proses pemberian atau penjatuhan pidana oleh hakim, sehingga dia mencakup keseluruhan ketentuan perundang-undangan yang mengatur bagaimana hukum pidana ditegakkan atau dioperasionalisasikan secara konkret sehingga seseorang dijatuhi sanksi (hukum) pidana (Barda Nawawi Arief, 2005, hal. 261).

Operasionalisasi hukum pidana secara konkret merupakan proses yang melibatkan hukum pidana materiil, hukum pidana formil dan hukum pelaksanaan pidana (Barda Nawawi Arief, 2005, hal. 262). Dalam proses demikian tampak ruang lingkup sistem pemidanaan meliputi hukum pidana materiil, hukum pidana formil dan hukum pelaksanaan pidana. Sistem pemidanaan demikian dimaknai sebagai pengertian yang luas sebagai keseluruhan sistem (aturan perundang-undangan) mengenai bagaimana hukum pidana itu ditegakkan atau dioperasionalkan secara konkret sehingga seseorang dijatuhi sanksi (hukum) pidana. Dengan pengertian demikian, Barda Nawawi Arief tegaskan, bahwa sistem pemidanaan identik dengan sistem penegakan hukum hidana yang terdiri dari sub-sistem Hukum Pidana Materiil / Substantif, sub-sistem Hukum Pidana Formil dan sub sistem Hukum Pelaksanaan Pidana (Barda Nawawi Arief, 2005, hal.261-262).

Dalam pengertian "substantif" sistem pemidanaan dilihat dari sudut normative / subjektif, yaitu dilihat dari norma-norma hukum(pidana). Sistem pemidanaan demikian sebagai keseluruhan sistem (aturan perundangan) untuk pemidanaan. Keseluruhan sistem (aturan perundangundangan) untuk pemberian / penjatuhan dan pelaksanaan pidana (Barda Nawawi Arief, 2007, hal.4). Sebagai suatu sistem, tersirat adanya keterjalinan utuh antara aturan perundang-undangan yang dituangkan dalam KUHP/WvS dengan aturan perundangundangan yang dirumuskan dalam ketentuan pidana di luar KUHP/WvS.

Pemahaman mengenai ruang lingkup sistem pemidanaan melalui pengkajian terhadap pengertian "sistem hukum pidana"dilihat dari sudut "sistem penegakan hukum pidana" yang kemudian dikenal dengan istilah "sistem pemidanaan" meliputi:

a. Substansi hukum pidana mencakup; subsistem hukum pidana materiil (KUHP/ WvS sebagai aturan induknya), subsistem hukum pidana formil (KUHAP sebagai aturan induknya), serta subsistem hukum pelaksanaan pidana (di antaranya Undang-undang No. 12 Tahun 1995 tentang Pemasyarakatan sebagai salah satu aturan sub-sistem hukum pelaksanaan pidana/administratif).

b. Struktur hukum pidana mencakup; lembaga, sistem manajemen/tatalaksana dan mekanimenya serta sarana/ prasarana pendukung dari sistem penegakan hukum pidana (sistem peradilan pidana)

c. Budaya hukum pidana mencakup; masalah kesadaran hukum, perilaku hukum dan ilmu hukum pidana (Barda Nawawi Arief, 2007 : 2).

Di sisi lain dalam "Reformasi Sistem Peradilan (Sistem Penegakaan Hukum) di Indonesia dikemukakan, bahwa yang dimaksud dengan nilai-nilai "budaya hukum" (legal culture) (L. Friedman, $1984: 2$ ) dalam konteks penegakan hukum, tentunya lebih terfokus pada nilai-nilai filosofi hukum, nilainilai hukum yang hidup dalam masyarakat dan kesadaran/sikap perilaku hukum/perilaku sosialnya, dan pendidikan/ilmu hukum. (Renstra (Rencana Strategik) Pembangunan Hukum Nasional Repelita VI (1994-1999).

Kebijakan sistem pemidanaan merupakan bagian dari kebijakan hukum pidana oleh karenanya dia juga merupakan usaha mewujudkan perundang-undangan pidana yang sesuai dengan keadaan dan situasi pada suatu waktu dan untuk masa-masa yang akan datang. Dengan demikian kebijakan sistem pemidanaan juga merupakan bagian dari pembaharuan Hukum Pidana. Hakikat pembaharuan hukum pidana mengandung makna suatu upaya untuk melakukan orientasi dan reformasi hukum pidana yang sesuai dengan nilai-nilai sentral sosio-politik, sosio-filosofik dan sosio-kultural masyarakat Indonesia yang melandasi kebijakan sosial, kebijakan kriminal dan kebijakan hukum di Indonesia. Secara singkat dapatlah dikatakan bahwa pembaharuan hukum pidana dan hakikatnya harus ditempuh dengan pendekatan yang berorientasi pada kebijakan ("policy-oriented approach") dan sekaligus pendekatan yang berorientasi 
pada nilai ("value-oriented approach") kebijakan pemidanaan. Pembaharuan hukum Pidana harus dilakukan dengan pendekatan kebijakan, karena memang pada hakikatnya ia hanya merupakan bagian dari suatu langkah kebijakan atau "policy" (yaitu bagian dari politik hukum/penegakan hukum, politik hukum pidana, politik kriminal dan politik sosial). Di dalam setiap kebijakan (policy) terkandung pula pertimbangan nilai. Oleh karena itu pembaharuan hukum pidana harus pula berorientasi pada pendekatan nilai (Barda Nawawi Arief, 2007 : 28). Sudah barang tentu terhadap kebijakan sistem pemidanaan pun harus perlu berorientasi pada pendekatan nilai.

Meskipun Sudarto tidak memberikan definisi pembaharuan hukum pidana, namun dalam salah satu tulisan beliau yang membahas "Makna Pembaharuan Hukum Pidana" diuraikan, apabila hukum pidana dipandang secara fungsional, dalam arti bagaimana perwujudan dan bekerjanya hukum pidana itu dalam masyarakat, maka dapat dilihat adanya tiga fase, ialah:

a. pengancaman pidana terhadap perbuatan (yang tidak disukai) oleh pembentukan undang-undang;

b. penjatuhan pidana kepada seseorang (korporasi) oleh hakim atas perbuatan yang dilakukan oleh orang (koorporasi) tersebut;

c. pelaksanaan pidana oleh aparat eksekusi pidana (misalnya lembaga pemasyarakatan) atas orang yang telah dijatuhi pidana tersebut. (Sudarto, 1979 :62).

Tentang pembaharuan hukum pidana dikatakan, bahwa tidak hanya meliputi hukum pidana materiil (substantif) saja, meskipun harus diakui, bahwa bagian hukum pidana yang memuat pengancaman dengan pidana terhadap suatu perbuatan orang (koorporasi) merupakan bagian yang penting. Kriminalisasi perbuatan-perbuatan yang tidak disukai masyarakat dan penentuan syarat-syarat apa yang harus dipenuhi sebelum seseorang dapat dipidana beserta pengancaman pidananya merupakan masalah yang sangat penting dan tidak mudah, yang kadangkadang tidak disadari benar oleh kebanyakan orang. Pembaharuan hukum pidana yang menyeluruh harus meliputi pembaharuan hukum pidana materiil (substantif), hukum pidana formil dan hukum pelaksanaan pidana (Sudarto, 1979 : 63; Sudarto, 1979 :
107). Ditegaskan juga oleh Sudarto, bahwa hukum pidana substantif memuat aturanaturan yang menetapkan dan merumuskan perbuatan-perbuatan yang dapat dipidana, aturan-aturan yang memuat syarat-syarat untuk menjatuhkan pidana dan ketentuan mengenai pidana (Sudarto, 1990 ; 10).

Pembaharuan Hukum Pidana yang saat ini masih dalam proses sampai dengan RUU KUHP Baru tahun 2012 dalam "penjelasan umum" ditegaskan, bahwa Penyusunan Kitab Undang-Undang Hukum Pidana Nasional yang baru untuk menggantikan Kitab Undang-Undang Hukum Pidana peninggalan pemerintah kolonial Belanda dengan segala perubahannya merupakan salah satu usaha dalam rangka pembangunan hukum nasional. Usaha tersebut dilakukan secara terarah dan terpadu agar dapat mendukung pembangunan nasional di berbagai bidang, sesuai dengan tuntutan pembangunan serta tingkat kesadaran hukum dan dinamika yang berkembang dalam masyarakat.

Dalam perkembangannya, makna pembaharuan Kitab Undang-Undang Hukum Pidana nasional yang semula sematamata diarahkan kepada misi tunggal yang mengandung makna "dekolonisasi" Kitab Undang-Undang Hukum Pidana dalam bentuk "rekodifikasi", dalam perjalanan sejarah bangsa pada akhirnya juga mengandung pelbagai misi yang lebih luas sehubungan dengan perkembangan baik nasional maupun internasional. Adapun misi kedua adalah misi "demokratisasi hukum pidana" yang antara lain ditandai dengan masuknya Tindak Pidana Terhadap Hak Asasi Manusia dan hapusnya tindak pidana penaburan permusuhan atau kebencian (haatzaaiartikelen) yang merupakan tindak pidana formil dan dirumuskan kembali sebagai tindak pidana penghinaan yang merupakan tindak pidana materiil. Misi ketiga adalah misi "konsolidasi hukum pidana" karena sejak kemerdekaan perundang-undangan hukum pidana mengalami pertumbuhan yang pesat baik di dalam maupun di luar Kitab UndangUndang Hukum Pidana dengan pelbagai kekhasannya, sehingga perlu ditata kembali dalam kerangka Asas-Asas Hukum Pidana yang diatur dalam Buku I Kitab UndangUndang Hukum Pidana. Di samping itu penyusunan Kitab Undang-Undang Hukum Pidana Baru dilakukan atas dasar misi keempat yaitu misi adaptasi dan harmonisasi terhadap pelbagai perkembangan hukum yang 
terjadi baik sebagai akibat perkembangan di bidang ilmu pengetahuan hukum pidana maupun perkembangan nilai-nilai, standar serta norma yang diakui oleh bangsa-bangsa beradab di dunia internasional.

Pembaharuan hukum pidana hakikinya adalah memperbaharui konsep berpikir, melakukan kegiatan yang bersifat filosofis seperti yang pernah dikemukakan oleh W. Ewald (dalam Esin drücü, Critical Comparative Law) mengemukakan, bahwa perbandingan hukum pada hakikatnya merupakan kegiatan yang bersifat filosofis (comparative law is an essentially philosophical activity). He gives a tentative definition as :"the comparative study of the intellectual conceptions that underline the principal institutions of one or more foreign legal systems". Perbandingan hukum adalah suatu studi atau kajian perbandingan mengenai konsepsi-konsepsi intelektual (intellectual conceptions) yang ada di balik institusi/lembaga hukum yang pokok dari satu atau beberapa sistem hukum asing (Barda Nawawi Arief, 2010 : 5).

Pandangan Ewald tentang philosophical activity dan intellectual conceptions meskipun diarahkan pada analisis perbandingan hukum(pidana) tidak menutup kemungkinan digunakan juga sebagai pisau analisis dalam pembahruan hokum pidana, karena seperti telah dikemukakan, bahwa hakikat pemebaharuan adalah memperbaharui konsepsi intelektual dan sekali gus merupakan kegiatan yang bersifat filosofis.

Mendasarkan pada konsep ini, pembahruan hukum pidana dalam RUU KUHP Baru 2012 lebih menegaskan, bahwa pemikiran mendasar lain yang mempengaruhi penyusunan Kitab Undang-Undang Hukum Pidana Baru adalah perkembangan ilmu pengetahuan tentang korban kejahatan (victimology) yang berkembang setelah Perang Dunia II, yang menaruh perhatian besar pada perlakuan yang adil terhadap korban kejahatan dan penyalahgunaan kekuasaan. Baik falsafah "Daad-dader Strafrecht" maupun viktimologi akan mempengaruhi perumusan 3 (tiga) permasalahan pokok dalam hukum pidana yaitu perumusan perbuatan yang bersifat melawan hukum, pertanggungjawaban pidana atau kesalahan dan sanksi (pidana dan tindakan) yang dapat dijatuhkan beserta asas-asas hukum pidana yang mendasarinya.

Pembaharuan Hukum Pidana materiil dalam RUU Kitab Undang-Undang Hukum
Pidana baru ini tidak membedakan lagi antara tindak pidana (strafbaarfeit) berupa kejahatan (misdrijven) dan tindak pidana pelanggaran (overtredingen). Untuk keduanya dipakai istilah tindak pidana. Dengan demikian, Kitab Undang-Undang Hukum Pidana baru nantinya hanya terdiri atas 2 (dua) Buku yaitu Buku Kesatu memuat Ketentuan Umum dan Buku Kedua yang memuat ketentuan tentang Tindak Pidana.

Dalam RUU Kitab Undang-Undang Hukum Pidana baru ini diakui pula adanya tindak pidana atas dasar hukum yang hidup dalam masyarakat atau yang sebelumnya dikenal sebagai tindak pidana adat untuk lebih memenuhi rasa keadilan yang hidup di dalam masyarakat. Adalah suatu kenyataan bahwa di beberapa daerah di tanah air, masih terdapat ketentuan-ketentuan hukum yang tidak tertulis, yang hidup dan diakui sebagai hukum di daerah yang bersangkutan, yang menentukan bahwa pelanggaran atas hukum itu patut dipidana. Dalam hal ini hakim dapat menetapkan sanksi berupa "Pemenuhan Kewajiban Adat" setempat yang harus dilaksanakan oleh pembuat tindak pidana. Hal ini mengandung arti, bahwa standar, nilai dan norma yang hidup dalam masyarakat setempat masih tetap dilindungi untuk lebih memenuhi rasa keadilan yang hidup di dalam masyarakat tertentu.

Terhadap dasar hukum yang hidup dalam masyarakat sebagai ketentuan-ketentuan hukum yang tidak tertulis, yang hidup dan diakui sebagai hukum harus digali oleh hakim dan hakim konstitusi (Undang-undang Kekuasaan Kehakiman Nomor 48 Tahun 2009, Pasal 5; "Hakim dan hakim konstitusi wajib menggali, mengikuti dan memahami nilai-nilai hokum dan rasa keadilan yang hidup dalam masyarakat").

2. Implementasi Jalinan Sistem Antara "General Rules" dengan "Special Rules" dalam Sistem Pemidanaan Substantif di Indonesia saat ini

Aturan Umum/"general rules" Pasal 1 sampai dengan Pasal 85/ Bab I sampai dengan Bab VIII Buku I KUHP/WvS yang terkait dalam jalinan sistem dengan Aturan Khusus/"special rules" dalam Buku II, III dan ketentuan pidana di luar KUHP/WvS dapat diidentifikasi sebagai berikut; tentang kualifikasi juridis (kejahatan dan pelanggaran), tentang kualifikasi keilmuan ( di antaranya mengenai "delik aduan"), tentang sistem 
penentuan volume pidana/strafmaat, tentang pedoman pemidanaan pidana pengganti denda.

Analisis terhadap ke empat identifikasi tersebut langsung dikaitkan jalinan sistemnya dengan aturan khusus dalam Buku II KUHP/ WvS dan aturan khusus dalam ketentuan perundang-undangan di luar KUHP/WvS (masing-masing dua ketentuan yang dipilih).

a. Kualifikasi Juridis (kejahatan dan pelanggaran)

Dalam Buku I KUHP/WvS tidak diformulasikan batasan juridis mengenai kejahatan dan pelanggaran, namun penyebutan kejahatan dan pelanggaran ada dalam formulasi pasal tertentu di antaranya Pasal 53; "(1) Mencoba melakukan kejahatan dipidana, jika niat untuk itu telah ternyata dari adanya permulaan pelaksanaan, dan tidak selesainya pelaksanaan itu, bukan semata-mata disebabkan karena kehendaknya sendiri. (2) Maksimum pidana pokok terhadap kejahatan, dalam hal percobaan dikurangi sepertiga. (3) Jika kejahatan diancam dengan pidana mati atau pidana penjara seumur hidup, dijatuhkan pidana penjara paling lama lima belas tahun. (4) Pidana tambahan bagi percobaan sama dengan kejahatan selesai". Pasal 54; "Mencoba melakukan pelanggaran tidak dipidana". Penyebutan kejahatan dan pelanggaran dalam formulasi Pasal 53 dan Pasal $54 \mathrm{KUHP} / \mathrm{WvS}$ terjalin secara sistem dengan kualifikasi juridis dengan Buku II (Kejahatan) dan Buku III(Pelanggaran).

Implentasi jalinan sistem tersebut dapat dianalisis dengan formulasi Pasal 351 KUHP/WvS; "(1) Penganiayaan diancam dengan pidana penjara paling lama dua tahun delapan bulan atau pidana denda paling banyak empat ribu lima ratus rupiah, (2) Jika perbuatan mengakibatkan luka-luka berat, yang bersalah diancam dengan pidana penjara paling lama lima tahun. (3) Jika mengakibatkan mati, diancam dengan pidana penjara paling lama tujuh tahun. (4) Dengan penganiayaan disamakan sengaja merusak kesehatan. (5) Percobaan untuk melakukan kejahatan ini tidak dipidana".

Formulasi Pasal 53 ayat (1); "Mencoba melakukan kejahatan dipidana,......", sedang formulasi
Pasal 351 ayat (5) ;" Percobaan untuk melakukan kejahatan ini tidak dipidana. Formulasi dua pasal tersebut terjalin secara sistem artinya dalam hal percobaan terkait dengan kejahatan. Penyimpangan formulasi dalam Pasal 351 ayat (5) dengan formulasi ketentuan induknya Pasal $53 \mathrm{KUHP} / \mathrm{WvS}$ ayat (1), dimungkinkan oleh ketetuan Pasal 103; "Ketentuan-ketentuan dalam Bab I sampai Bab VIII buku ini juga berlaku bagi perbuatan- perbuatan yang oleh ketentuan perundang-undangan lainnya diancam dengan pidana, kecuali jika oleh undang-undang ditentukan lain".

Tentang kualifikasi juridis berupa kejahatan atau pelanggaran tidak senantiasa dicermati oleh anggota legistatif dalam kebijakan formulasi ketentuan perundang-undangan di Indonesia, di antaranya formulasi UndangUndang Nomor 3 tahun 1971 Tentang Pemberantasan Tindak Pidana Korupsi.

Dalam formulasi ketentuan Pasal 33 nya disebutkan; "Perbuatan-perbuatan yang diancam dengan hukuman yang tersebut dalam Pasal 28 sampai dengan Pasal 32 Undang-undang ini adalah kejahatan". Kualifikasi juridis kejahatan dalam undang-undang ini tentu berdampak juridis di samping, Percobaan (Pasal 53, Pasal 54 KUHP/WvS), Asas Nasional Aktif (Pasal 5 ayat 1 ke 2 KUHP/WvS), Penyertaan/Pembantuan (Pasal 56 dan Pasal 57 KUHP/ WvS), Concursus (Pasal 63 sampai dengan Pasal 71 KUHP/WvS), Perihal Pengaduan ( Pasal 72 sampai dengan Pasal 75), Alasan hapusnya kewenangan menuntut dan menjalankan pidana ( Pasal 78 dan Pasal 84 KUHP/WvS).

b. Kualifikasi keilmuan ("delik aduan") Implentasi jalinan sistem "delik aduan" dapat dianalisis dengan formulasi Pasal 284;

(1) Diancam dengan pidana penjara paling lama sembilan bulan:

1. a. seorang pria yang telah kawin yang melakukan gendak (overspel), padahal diketahui bahwa pasal 27 BW berlaku baginya,

b. seorang wanita yang telah kawin yang melakukan gendak, padahal diketahui bahwa pasal 27 BW berlaku baginya; 
2. a. seorang pria yang turut serta melakukan perbuatan itu, padahal diketahuinya bahwa yang turut bersalah telah kawin;

b. seorang wanita yang telah kawin yang turut serta melakukan perbuatan itu, padahal diketahui olehnya bahwa yang turut bersalah telah kawin dan pasal 27 BW berlaku baginya.

(2) Tidak dilakukan penuntutan melainkan atas pengaduan suami/ istri yang tercemar, dan bilamana bagi mereka berlaku pasal $27 \mathrm{BW}$, dalam tenggang waktu tiga bulan diikuti dengan permintaan bercerai atau pisah-meja dan ranjang karena alasan itu juga.

(3) Terhadap pengaduan ini tidak berlaku pasal 72, 73, dan 75 .

(4) Pengaduan dapat ditarik kembali selama pemeriksaan dalam sidang pengadilan belum dimulai.

(5) Jika bagi suami-istri berlaku pasal 27 BW, pengaduan tidak diindahkan selama perkawinan belum diputuskan karena perceraian atau sebelum putusan yang menyatakan pisah meja dan tempat tidur menjadi tetap.

Implementasi jalinan sistem formulasi Pasal 284 dengan formulasi ketentuan;

"Bab VII - Mengajukan Dan Menarik Kembali Pengaduan Dalam Hal Kejahatan-Kejahatan Yang Hanya Dituntut Atas Pengaduan"

Pasal 72;

"(1) Selama orang yang terkena kejahatan yang hanya boleh dituntut atas pengaduan, dan orang itu umurnya belum cukup enam belas tahun dan lagi belum dewasa, atau selama ia berada di bawah pengampuan yang disebabkan oleh hal lain daripada keborosan, maka wakilnya yang sah dalam perkara perdata yang berhak mengadu";

"(2) Jika tidak ada wakil, atau wakil itu sendiri yang harus diadukan, maka penuntutan dilakukan atas pengaduan wali pengawas atau pengampu pengawas, atau majelis yang menjadi wali pengawas atau pengampu pengawas; juga mungkin atas pengaduan istrinya atau seorang keluarga sedarah dalam garis lurus, atau jika itu tidak ada, atas pengaduan seorang keluarga sedarah dalam garis menyimpang sampai derajat ketiga".

Pasal 73;

"Jika yang terkena kejahatan meninggal di dalam tenggang waktu yang ditentukan dalam pasal berikut maka tanpa memperpanjang tenggang itu, penuntutan dilakukan atas pengaduan orang tuanya, anaknya, atau suaminya (istrinya) yang masih hidup kecuali kalau ternyata bahwa yang meninggal tidak menghendaki penuntutan".

Pasal 74;

“(1) Pengaduan hanya boleh diajukan dalam waktu enam bulan sejak orang yang berhak mengadu mengetahui adanya kejahatan, jika bertempat tinggal di Indonesia, atau dalam waktu sembilan bulan jika bertempat tinggal di luar Indonesia".

"(2) Jika yang terkena kejahatan berhak mengadu pada saat tenggang waktu tersebut dalam ayat 1 belum habis, maka setelah saat itu, pengaduan masih boleh diajukan hanya selama sisa yang masih kurang pada tenggang waktu tersebut".

Pasal 75;

"Orang yang mengajukan pengaduan, berhak menarik kembali dalam waktu tiga bulan setelah pengaduan diajukan".

Implementasi jalinan sistem formulasi Pasal 284 dengan ketentuan "syarat pengaduan" ada dalam ayat (3) Terhadap pengaduan ini tidak berlaku pasal 72, 73, dan 75. Formulasi ketentuan ayat (3) ini dimungkinkan oleh ketentuan Pasal 103 dan terhadap ketentuan pengaduan dalam Pasal 284 salah satunya tetap diberlakukan ketentuan Pasal 74 KUHP/WvS dan dengan menggunakan analisis logika juridis, maka dapat dijelaskan bahwa terhadap syarat pengaduan ketentuan Pasal 284 mengatur sendiri substansi formulasinya yang tidak jauh berbeda dengan formulasi Pasal 72 dan Pasal 75. Berikut penjelasannya. 
Formulasi ketentuan Pasal 72 substansinya mengenai "hak pengaduan" bagi orang umurnya belum cukup enam belas tahun dan lagi belum dewasa" dan karena tindak pidana zina itu hak pengaduan ada pada suami atau istri yang tercemar, maka ketentuan pengaduannya ada dalam formulasi Pasal 284 ayat (2) Tidak dilakukan penuntutan melainkan atas pengaduan suami/istri yang tercemar, dan bilamana bagi mereka berlaku pasal $27 \mathrm{BW}$, dalam tenggang waktu tiga bulan diikuti dengan permintaan bercerai atau pisah-meja dan ranjang karena alasan itu juga.

Formulasi ketentuan Pasal 73 substansinya mengenai pengganti yang berhak mengadu jika yang berhak mengadu meninggal dunia. Ketentuan demikian tidak diformulasikan dalam Pasal 284. Formulasi ketentuan Pasal 75 substansinya mengenai "hak menarik kembali pengaduan yang diajukan". Dalam tndak pidana zina hak menarik kembali pengaduan diatur tersendiri dalam formulasi Pasal 284 ayat (4) "Pengaduan dapat ditarik kembali selama pemeriksaan dalam sidang pengadilan belum dimulai".

Terhadap kualifikasi keilmuan di antaranya "delik aduan "inipun tidak disikapi secara cermat oleh anggota Badan Legislatif ketika melakukan formulasi Undang-Undang Nomor 23 Tahun 2004 tentang Penghapusan Kekerasan Dalam Rumah Tangga. Formulasi pasal berikut ini merupakan contoh kebijakan legislative yang tidak berpola. Pasal-pasal tersebut adalah; Pasal 51 Tindak pidana kekerasan fisik sebagaimana dimaksud dalam Pasal 44 ayat (4) merupakan delik aduan. Pasal 52 Tindak pidana kekerasan psikis sebagaimana dimaksud dalam Pasal 45 ayat (2) merupakan delik aduan. Pasal 53 Tindak pidana kekerasan seksual sebagaimana dimaksud dalam Pasal 46 yang dilakukan oleh suami terhadap isteri atau sebaliknya merupakan delik aduan. Penyebutan "delik aduan" di tiga pasal di atas jelas menyimpang dari norma keilmuannya, karena kualifikasi keilmuan seperti "delik aduan" bukan ditetapkan oleh badan pembentuk undang-undang. Penyebutan "delik aduan" ditegaskan oleh ilmu pengetahuan hukum pidana.
Formulasi ketentuan Pasal 51, 52 dan 53 di atas, seharusnya berisi; siapa yang berhak mengajukan pengaduan, tenggang waktu pengaduan, tenggang waktu menarik kembali pengaduan.

Persyaratan pengaduan demikian tidak terdapat dalam formulasi ketentuan Pasal 51, 52 dan 53 dan anehnya formulasi yang berhubungan dengan $\mathrm{Bab}$ "Perlindungan" dalam Pasal 16, 19, 26 dan 27 ternyata menyebut "laporan";

Pasal 16; "Dalam waktu $1 \times 24$ (satu kali dua puluh empat) jam terhitung sejak mengetahui atau menerima laporan kekerasan dalam rumah tangga, kepolisian wajib segera memberikan perlindungan sementara pada korban".

Pasal 19; "Kepolisian wajib segera melakukan penyelidikan setelah mengetahui atau menerima laporan tentang terjadinya kekerasan dalam rumah tangga".

Pasal 26; "Korban berhak melaporkan secara langsung kekerasan dalam rumah tangga kepada kepolisian baik di tempat korban berada maupun di tempat kejadian perkara.

Korban dapat memberikan kuasa kepada keluarga atau orang lain untuk melaporkan kekerasan dalam rumah tangga kepada pihak kepolisian baik di tempat korban berada maupun di tempat kejadian perkara".

Pasal 27; "Dalam hal korban adalah seorang anak, laporan dapat dilakukan oleh orang tua, wali, pengasuh, atau anak yang bersangkutan yang dilaksanakan sesuai dengan ketentuan peraturan perundang-undangan yang berlaku".

Masalah juridis dalam kebijakan formulasi hokum pidana dalam Undangundang Penghapusan dalam Rumah Tangga / UU N0. 23 Tahun 2004 dapat disimpulkan sebagai "prahara kebijakan perundang-undangan" di Indonesia.

\section{c. Sistem penentuan volume pidana/ strafmaat}

Sistem penentuan volume pidana/ strafmaat dapat dianalisis dengan berpedoman ketentuan Pasal 12 ayat (2) "Pidana penjara selama waktu tertentu paling pendek satu hari dan paling lama lima belas tahun berturut-turut". Terlihat sistem penentuan strafmaat menggunakan "sistem minimal umum 
dan sistem maksimal umum". Sistem penentuan strafmaat tersebut dapat dilengkapi dengan memahami ketentuan dalam aturan khususnya di antaranya Buku II(kejahatan). Ketentuan pidana dalam formulasi Pasal 338; “...... diancam karena pembunuhan dengan pidana penjara paling lama lima belas tahun". Ketentuan pasal tersebut dan semua pasal dalam BUKU II dan III menggunakan sistem maksimal khusus.

Sistem penentuan volume pidana/ strafmaat dalam KUHP/WvS meliputi; "sistem minimal umum, sistem maksimal umum dan sistem maksimal khusus". Penetuan demikian memberikan pemahaman, bahwa Sistem penentuan volume pidana/ strafmaat dalam KUHP/ WvS tidak mencantumkan "sistem minimal khusus".

Implementasi jalinan sistem strafmaat dapat dianalisis dengan ketentuan Pasal 2 Undang-Undang Nomor 31 Tahun 1999 tentang "Pemberantasan Tindak Pidana Korupsi”; "(1) Setiap orang yang secara melawan hukum melakukan perbuatan memperkaya diri sendiri atau orang lain atau suatu korporasi yang dapat merugikan keuangan negara atau perekonomian negara, dipidana penjara dengan penjara seumur hidup atau pidana penjara paling singkat 4 (empat) tahun dan paling lama 20 (dua puluh) tahun dan denda paling sedikit Rp. 200.000.000,00 (dua ratus juta rupiah) dan paling banyak Rp. 1.000.000.000,00 (satu milyar rupiah). (2) Dalam hal tindak pidana korupsi sebagaimana dimaksud dalam ayat (1) dilakukan dalam keadaan tertentu, pidana mati dapat dijatuhkan.

Strafmaat dalam pasal di atas menggunakan sistem minimal khusus di samping maksimal khusus. Dikaitkan dengan sistem induk, jalinan sistemnya ada pada "maksimal khusus", sedang "minimal khusus" meskipun tidak terjalin sistem, dimungkan oleh ketentuan Pasal 103. Masalahnya apakah dalam penerapan pidana oleh hakim, dapat dijatuhkan "lebih ringan" dari minimal khususnya. Kebijakan menjatuhkan pidana lebih ringan dari minimal khusus hanya mungkin jika dilandaskan pada"pedoman pemidanaan" bagi ancaman pidana minimal khusus. Pedoman demikian tidak ada dalam ketentuan UU No. 31 th. 1999. Kenyataan ini menjadi kendala bagi penerapan pidana minimal khusus.

Analisis terhadap makna "lebih ringan dari minimal khusus" dapat dikaitkan dengan ketentuan induk Buku I yang mengatur substansi "meringankan" seperti ketentuan Pasal 53 ayat (2) KUHP/WvS; " Maksimum pidana pokok terhadap kejahatan, dalam hal percobaan dikurangi sepertiga". Implementasi jalinan sistem Pasal 53 ayat (2) dengan Pasal 2 UU No. 31 th. 1999 (catatan; bahwa ketentuan Pasal 2 ini harus berkualifikasi "kejahatan") dalam hal pidana minimal khusus, maka yang dapat dikurangi hanyalah ancaman maksimal pidana pokonya. Jika analisisnya disandarkan pada "pidana pokok", maka seharusnya pidana minimal khusus inipun dapat dipertimbangkan untuk dikurangi dan tentu tidak menggunakan dasar Pasal 53 ayat (2). Oleh karena itu dalam UU No. 31 th. 1999 perlu ada "pedoman pemidanaa" untuk implementasi pidana minimal khusus.

d. Pedoman pemidanaan pidana pengganti denda.

Implementasi jalinan sistem antara jenis pidana denda dalam Pasal 10 KUHP/WvS dengan pidana denda dalam Pasal 2 Undang-Undang Nomor 31 Tahun 1999 tentang Pemberantasan Tindak Pidana Korupsi merupakan hal wajar dalam sistem pemidanaan. Volume pidana denda yang besar memang terkait dengan tujuan pemberantasan tindak pidana korupsi di antaranya upaya pemiskinan pelaku tindak pidana. Secara teoritik upaya demikian bisa jauh dari harapan karena pelaku tidak mau membayar jumlah pidana denda yang dijatuhkan, sehingga masalahnya terkait dengan "pedoman pemidanaan" bagi denda yang tidak dibayar. Pedoman/ Aturan pemidanaan untuk denda yang tidak dibayar tidak diformulasikan dalam Undang-Undang Tindak Pidana Korupsi, sehingga secara sistem berlakulah aturan/pedoman pemidanaan dalam induknya/KUHP (Pasal 30). Kenyataan demikian bukanlah merupakan masalah juridis, tetapi jika dianalisis dari volume pengganti denda yang tidak dibayar, yaitu setiap Rp.7,50 (tujuh rupiah lima puluh sen) kurungan penggantinya 1 (satu) 
hari, maka maksimal kurungan pengganti denda adalah 6 (enam) bulan, kecuali ada pemberatan pidana denda seperti perbarengan, kurungan penggantinya maksimal 8 (delapan). Secara matematis Rp.1000,- pidana denda tidak dibayar, kurungan penggantinya selama 134 (seratus tiga puluh empat hari/4 bulan 2 minggu), Rp.2000,- kurungan penggantinya 9 (sembilan bulan) dan pelaku hanya menjalani kurungan pengganti 6 (enam bulan). Pemahaman seperti ini, membuat pelaku tindak pidana korupsi cenderung memilih kurungan pengganti denda daripada harus membayar denda yang dijatuhkan.

Fakta penjatuhan pidana denda sebagai "prahara kebijakan perundangundangan" dapat dilihat dari putusan hakim TIPIKOR yang mengadili pelaku tindak pidana korupsi Jenderal Joko Susilo. Majelis hakim Pengadilan Tindak Pidana Korupsi Jakarta, Suhartoyo, Selasa (3/9), menyatakan mantan Kepala Korps Lalu Lintas (Korlantas) Mabes Polri Inspektur Jendral (Irjen) Djoko Susilo, terbukti bersalah melakukan tindak pidana korupsi dalam pengadaan driving simulator Surat Izin Mengemudi (SIM) di Korlantas Polri tahun anggaran 20102011. "Menyatakan terdakwa Inspektur Jendral Polisi Djoko Susilo telah terbukti secara sah dan meyakinkan menurut hukum bersalah melakukan tindak pidana korupsi secara bersama-sama dan gabungan beberapa kejahatan. Menjatuhkan pidana terhadap terdakwa berupa pidana penjara selama 10 tahun. Dan pidana denda sebesar Rp 500 juta subsider enam bulan kurungan," demikian keputusan yang dibacakan oleh Suhartoyo.

Selain itu menurut Suhartoyo, terdakwa terbukti melakukan tindak pidana pencucian uang dengan cara menyamarkan, mengalihkan, mentransfer, membelanjakan atau merubah bentuk harta maupun aset yang patut diduga berasal dari tindak pidana dalam kurun waktu 2003-2010 hingga berjumlah Rp 54,6 Miliar dan 60 ribu dolar Amerika. Aset itu kini, dirampas untuk negara (http://www.voaindonesia. com/content/pengadilan-vonis-jenderaldjoko-susilo-10-tahun-penjara/1742371. html).
Putusan hakim tentang besarnya denda dan kurungan penggatinya sangat disadari oleh hakim, bahwa kurungan pengganti enam bulan tersebut didasarkan pada ketentuan Pasal $30 \mathrm{KUHP} / \mathrm{WvS}$. Hakim mestinya menganalisis tentang kecilnya volume kurungan penggati tersebut didasarkan pada besarnya denda Rp. 7,50 yang tidak dibayar diganti dengan kurungan pengganti 1 hari. Ketentuan demikian tentu tidak layak untuk menjadi dasar putusan hakim. Hakim sebenarnya bisa berpijak dari formulasi ketentuan Pasal 18 ayat 1 huruf b Undang-Undang Nomor 31 Tahun 1999 tentang Pemberantasan Tindak Pidana Korupsi; "Pembayaran uang pengganti .........". Formulasi ketentuan ayat 2 dan 3; "Jika terpidana tidak membayar uang pengganti.

maka harta bendanya dapat disita oleh jaksa dan dilelang untuk menutupi uang pengganti tersebut. Jika harta benda terpidana tidak mencukupi, maka dipidana dengan pidana penjara yang lamanya tidak melebihi ancaman maksimum dari pidana pokoknya dan lamanya pidana tersebut ditentukan dalam putusan pengadilan".

Pedoman pemidanaan terhadap pidana tambahan berupa uang pengganti yang tidak dipenuhi dalam formulasi ketentuan tersebut dapat dijadikan rujukan untuk pidana denda sebesar lima ratus juta rupiah, bukan kurungan pengganti. Dalam formulasi tersebut pidana tambahan uang pengganti disetarakan dengan pidana denda.

Analisis di atas tentu tidak hanya berlaku bagi undang-undang korupsi, ketentuan perundang-undangan lainnya jika tidak dilengkapi dengan formulasi aturan/pedoman pemidanaan pengganti denda yang tidak dibayar, maka bukan hanya matematika di atas yang berlaku, tetapi pedoman pemidanaan untuk uang penggati dapat menjadi rujukan bagi hakim TIPIKOR.

Implementasi jalinan sistem antara "general rules" dengan "special rules" dalam sistem pemidanaan substantif tidak dapat dipisahkan dengan kebijakan sistem pemidanaan yang akan ditempuh oleh anggota DPR dalam memahami semua permasalahan juridis yang ada untuk membuat yang lebih baik. 
3. Implementasi jalinan sistem antara general rules dengan special rules dalam sistem pemidanaan substantif yang akan datang

Implementasi jalinan sistem antara general rules dengan special rules dalam sistem pemidanaan substantif yang akan datang menggunakan dasar analisis RUU KUHP Baru Tahun 2012.

Formulasi ketentuan dalam RUU KUHP Baru Tahun 2012 yang hampir sama dengan ketentuan Pasal 103 KUHP/WvS ada dalam Pasal 211 Bab VI Ketentuan Penutup sebagai berikut; "Ketentuan dalam Bab I sampai dengan Bab V Buku Kesatu berlaku juga bagi perbuatan yang dapat dipidana menurut peraturan perundang undangan lain, kecuali ditentukan lain menurut peraturan perundangundangan tersebut".

Perbedaan substansi formulasi ketentuan penutup tersebut pada Bab $\mathrm{V}$ tentang "Pengertian Istilah" RUU KUHP Baru berlaku juga bagi perbuatan yang dapat dipidana menurut peraturan perundang undangan lain, kecuali ditentukan lain menurut peraturan perundang-undangan tersebut, sedang $\mathrm{Bab}$ IX KUHP/WvS tentang "Arti Beberapa Istilah Yang Dipakai Dalam Kitab Undang-Undang hanya berlaku bagi formulasi ketentuan Buku II dan Buku III.

Formulasi yang baru sama sekali ketentuan dalam Buku I RUU KUHP Baru yang dapat diimplementasikan dalam formulasi ketentuan pidana di luarnya di antaranya adalah ketentuan Pasal 67 (1) Pidana tambahan terdiri atas:

a. pencabutan hak tertentu;

b. perampasan barang tertentu dan/atau tagihan;

c. pengumuman putusan hakim;

d. pembayaran ganti kerugian; dan

e. pemenuhan kewajiban adat setempat atau kewajiban menurut hukum yang hidup dalam masyarakat.

Pemenuhan kewajiban adat setempat atau kewajiban menurut hukum yang hidup dalam masyarakat terkait dengan kewajiban hakim dalam menggali, mengikuti dan memahami nilai-nilai hukum yang hidup dalam masyarakat pernah dijadikan dasar penjatuhan pidana oleh hakim Bismar Siregar dalam putusannya di bawah ini.

Putusan Pengadilan Tinggi Medan Nomor 144/Pid/1983/Pt Mdn dalam putusan hakim tanggal 8-8-1983 No. 144/Pid/PTMdn telah memberikan arti bonda(bahasa Batak) dari unsur benda (goed) dalam penipuan adalah juga temasuk alat kelamin wanita. Petimbangan PengadilanTinggi Medan mengenai hal ini sebagai berikut, bahwa walaupun berlebihan, khusus dan teutama dalam perkara ini tentang istilah barang, dalam bahasa daerah terdakwa dan saksi (Tapanuli) dikenal istilah bonda yang tidak lain daripada barang, yang diartikan kemaluan sehingga bilsa saksi K.br.S menyerahkan kehormatannya kepada terdakwa samalah dengan menyerahkan benda/barang (https:// www.google.co.id/\#q=Putusan+Pengadilan+ Tinggi+Medan+Nomor+144\%2FPid\%2F1983 $\% 2 \mathrm{FPt}+\mathrm{Mdn}$ ).

Putusan di atas pada intinya didasarkan pada kasus tentang hubungan suka sama suka seorang pria dan wanita yang berujung pada diserahkannya kehormatan si wanita karena janji pria yaitu; nikah dan kesejahteraan seumur hidup. Pria tersebut ternyata mengingkari janjinya. Kata kunci "menyerahkan kehormatan" wanita kepada pria dalam kasus ini di Pengadilan Tinggi Medan ditangani langsung oleh Bismar Siregar. Bismar menganalisis perbuatan "menyerahkan kehormatan" oleh wanita dikaitkan dengan "ingkar janji" pria dari hubungan suka sama suka "memenuhi unsur Pasal 378 KUHP/WvS; "Barang siapa dengan maksud menguntungkan diri sendiri atau orang lain secara melawan hukum dengan memakai nama palsu atau martabat palsu, dengan tipu muslihat atau rangkaian kebohongan menggerakkan orang lain untuk menyerahkan barang sesuatu kepadanya, atau supaya memberi hutang, atau menghapuskan piutang, diancam karena penipuan dengan pidana penjara paling lama empat tahun".

Analisis pertimbangan Bismar didasarkan pada amanah Pasal 5 Undang-Undang Kekuasaan Kehakiman Nomor 48 Tahun 2009; "Hakim dan hakim konstitusi wajib menggali, mengikuti dan memahami nilai-nilai hukum dan rasa keadilan yang hidup dalam masyarakat" dan putusannya tertuang dalam Putusan Pengadilan Tinggi Medan tanggal 8-8-1983 Nomor 144/Pid/1983/Pt No. 144/ Pid/PTMdn. telah memberikan arti "barang" / bonda(bahasa Batak) dari unsur benda (goed) dalam penipuan adalah juga temasuk alat kelamin wanita atau kemaluan sehingga bilsa wanita yang merupakan saksi dalam kasus tersebut menyerahkan kehormatannya 
kepada pria/ terdakwa samalah dengan menyerahkan benda/barang.

Kebijakan formulasi pidana tambahan Pasal 67 RUU KUHP Baru 2012 ada dalam Buku Kesatu tentang Ketentuan Umum, menurut formulasi ketentuan Pasal 211; "Ketentuan dalam Bab I sampai dengan Bab V Buku Kesatu berlaku juga bagi perbuatan yang dapat dipidana menurut peraturan perundang undangan lain, kecuali ditentukan lain menurut peraturan perundang-undangan tersebut.

Ketentuan dalam Bab I sampai dengan Bab V Buku Kesatu ada dalam Pasal 1 sampai dengan Pasal 210, sehingga formulasi pidana tambahan "pemenuhan kewajiban adat setempat atau kewajiban menurut hukum yang hidup dalam masyarakat" berlaku juga bagi perbuatan yang dapat dipidana menurut peraturan perundang undangan lain, kecuali ditentukan lain menurut peraturan perundangundangan tersebut.

Dengan demikian implementasi jalinan sistem antara general rules dengan special rules dalam sistem pemidanaan substantif yang akan datang dapat mengikuti konsepsi intelektual atau kegiatan yang bersifat filosofis yang telah dilakukan oleh hakim Bismar Siregar sebagai wujud diakuinya hukum yang hidup dalam masyarakat sebagai sumber/ dasar hukum(asas legalitas materiil) dalam menjatuhkan pidana di samping sumber/ dasar hukum tertulis/undang-undang (asas legalitas formil).

\section{d. Simpulan}

Implementasi jalinan sistem antara "general rules" dengan "special rules" dalam sistem pemidanaan substantif di Indonesia saat ini tidak senantiasa ideal, karena terabaikannya pemahaman atas sistem pemidanaan dalam ketentuan induknya di KUHP/WvS. Kondisi demikian bisa akan lebih rumit lagi ketika RUU KUHP Baru dengan indikasi kebaharuannya tidak disikapi secara cerdas oleh Badan Legislatif dalam kebijakan formulasinya.

\section{E. Saran}

Sistem pemidanaan dalam ketentuan induk KUHP/WvS selama masih dicatumkan dalam kurikulum Hukum Pidana pada Pendidikan Tinggi Hukum harus dipadukan dengan sistem pemidanaan dalam RUU KUHP Baru, sehingga terjadi perkembangan pemahaman mahasiswa tentang sistem pemidanaan Indonesia, karena hakikat pembaharuan hukum pidana adalah pembaharuan konsepsi inteletual atau suatu kegiatan yang bersifat filosofis. 


\section{daftar Pustaka}

Arief, Barda Nawawi. 2001. Masalah penegakan Hukum dan Kebijakan penanggulangan Kejahatan. Bandung: PT. Citra Aditya Bakti.

- Beberapa Aspek Pengembangan Ilmu Hukum Pidana (Menyongsong Generasi Baru Hukum pidana Indonesia), Pidato Pengukuhan, Diucapkan Pada Peresmian Penerimaan Jabatan Guru Besar Dalam IImu Hukum Pada Fakultas Hukum Universitas Diponegoro, Semarang 25 Juni 1994.

_. 1998. Beberapa Aspek Kebijakan Penegakan dan Pengembangan Hukum Pidana. Bandung: PT Citra Aditya Bakti.

- 2005. Bunga rampai Kebijakan Hukum pidana. Bandung: Citra Additya Bakti.

- 2006. Kapita Selekta Hukum pidana tentang Sistem peradilan pidana Terpadu(Integrated criminal Justice System). Semarang: Badan Penerbit Universitas Diponegoro.

- 2003. Kapita Selekta Hukum pidana. Bandung: Citra Additya Bakti.

. 2005. pembaharuan Hukum pidana Dalam perspektif Kajian perbandingan. Bandung: Citra Additya Bakti.

- 2007. perkembangan System pemidanaan di Indonesia. Semarang: Penerbit Pustaka. Magister.

. 2007. rUU KUHp Baru, Sebuah restrukturisasi/rekonstruksi Hukum pidana Indonesia, Semarang: Pustaka Magister.

- 2009. Tujuan Dan pemidanaan pemidanaan perspektif pembaharuan Hukum pidana dan perbandingan Beberapa Negara. Semarang: Badan Penerbit Universitas Diponegoro.

- 2010. perbandingan Hukum pidana. Semarang: Badan Penerbit Universitas Diponegoro.

Hulsman , L.H.C. 1988. Selamat Tinggal Hukum pidana. Menuju Swa regulasi. Surakarta: Forum Studi Hukum Pidana.

L. Friedman. 1984. "What Is a Legal System" dalam American Law. W.W. Norton \& Company, New York, Muladi dan Barda Nawawi Arief. 1992. Teori - Teori dan Kebijakan Pidana. Bandung: Alumni.

- id.wikipedia.org/wiki/Terorisme - Terorisme, dari Wikipedia bahasa Indonesia, ensiklopedia bebas

- 1990. proyeksi Hukum pidana Materiil Indonesia di Masa Mendatang, Pidato Pengukuhan Jabatan Guru Besar IImu Hukum Pidana. Semarang: Fakultas Hukum Undip.

Moeljatno. 1999. Kitab Undang-Undang Hukum pidana. Jakarta: Bumi Aksara.

Sudarto. 1986. Hukum Dan Hukum pidana. Bandung: Alumni.

_. 1983. Hukum pidana dan perkembangan Masyarakat, Kajian Terhadap pembaharuan Hukum pidana. Bandung: Sinar Baru.

—. 1979. Suatu Dilemma Dalam pembaharuan Sistim pidana Indonesia. Semarang: Fakultas Hukum UNDIP.

-. 1990. Hukum pidana I. Semarang: Fakultas Hukum UNDIP.

https://www.google.co.id/\#q=Putusan+Pengadilan+Tinggi+Medan+Nomor+144\%2FPid\%2F1983\%2FP $\mathrm{t}+\mathrm{Mdn}$

Rancangan Undang-Undang Kitab Undang-Undang Hukum Pidana Tahun 2012 